\title{
Masters of Italian Renaissance
}

\section{Dorin Mircea SIMIONESCU*}

\begin{abstract}
The Renaissance period in Italy determined the genesis of professional music which would afterwards have a fulminating evolution around the world. The composers' preferences most often favoured vocal music, which at the time had a greater ability of expression in comparison with the musical instruments and which therefore reached its peak. The choral creation of the Renaissance is remarkable by the astounding evolution of genres and musical forms. The most significant representatives of this period are Giovanni Pierluigi da Palestrina, Luca Marenzio, Carlo Gesualdo and Claudio Monteverdi. Monteverdi stands as the last important composer of the golden age of the a cappella choral creation, leaving an invaluable heritage due to his polyphonic and instrumental music, while his dramatic madrigals envision him as a precursor of the opera.
\end{abstract}

Keywords: Renaissance, culture, music, Renaissance music, madrigal, counterpoint, motet, polyphony.

The Renaissance represents a period of blooming and brilliant flourishing, of general evolution of the European society both in social and economic aspects, as well as in scientific, philosophical, cultural and artistic ones.

* PhD candidate, Faculty of Orthodox Theology at "1 Decembrie 1918" University of Alba Iulia, Romania. 
The end of the Middle Ages, the fourteemth-sixteenth centuries, brings to mind the ancient Greek humanism adapted to the Christian ideology. The sinful man, under the pressure felt by the greatness of the divinity, as it appears in medieval culture, is gradually replaced, first in secular and afterwards in the religious culture, with the Man - as an image of divinity ${ }^{l}$ created in the image and likeness of God. The Renaissance art turns its attention again, like the ancient Greeks, to the exterior of man, to beauty and physical perfection, interpreting it as a reflection of the spirit.

The first manifestations of the Renaissance took place in Italy. After the Peace of Lodi (1454), there was a balance between the various political forces that led to a period of relative amity and, consequently, the economic development of the cities of central and northern Italy, favouring the flourishing of art and literature, encouraged and financially supported by the wealthy and influential families like the Medici of Florence, Este of Ferrara, Sforza of Milan, and the Dukes of Urbino, the Doges of Venice and the Roman papacy.

As a result of the development of the cities, there is a new, growing, wealthy, stronger social category, namely the craftsmen, the merchants, the pawnbrokers / the bankers, gradually imposing a new secular and religious culture.

Johann Gutenberg's invention of the printing press and the great geographic discoveries set their mark on the development of all mankind, creating the premises for the epochs that followed.

The Renaissance spirit is dynamic, provoking change, looking for the new, in contrast with the medieval spirit, which was the static guardian of tradition. This led to the unprecedented development of science. Some names with strong resonances of this period are Leonardo da Vinci (1452-1519), Nicolaus

${ }^{1}$ Max Eisikovits, Polifonia vocală a Renașterii. Stilul palestrinian, Editura Muzicală, București, 1966, pag. 86 
Copernicus (1473-1543), Giordano Bruno (1548-1600), Galileo Galilei (1564-1642) and many others.

The encyclopedic spirit, symmetry, simplicity and balance were cultivated.

A series of important historical events such as the discovery of the Americas, the rise of colonial powers such as Spain, England, France, Portugal and the Netherlands, the rise of the Ottoman Empire, and in 1453 the conquest of Constantinople leading to the disappearance of the Byzantine Empire.

There are important reforms in religion: - the spread of Protestantism, the Anglican Church established by Henry VIII, the theological writings of John Calvin. After 1540, the Catholic Church triggered the Counter-Reformation, establishing the Order of the Jesuits and the Inquisition.

The centre of the Western European culture during this period was represented by the Italian city-states which were under continuous development: Rome, Florence, Venice, Naples, Milan, Genoa, Ferrara and Palermo ${ }^{2}$.

A special place in Renaissance literature is occupied by writers - poets: Dante Alighieri (1265-1321), Francesco Petrarca (1304-1374), Giovanni Boccaccio (1313-1375) and Niccolo Machiavelli (1469-1527).

Painting, sculpture and architecture include sounding names such as: Leonardo da Vinci (1452-1519), Michelangelo Buonarroti (1475-1564), Rafael Sanzio (1483-1520) and many others.

The culture of the Greek antiquity became the preoccupation and model of the Renaissance. During this period, the interchange of religious - folk - cultivated art and among different cultures was continued and intensified: West-East,

2 Mario Carrozzo - Cristina Cimagallia: Storia della musica occidentale, Armando Editore, Roma 2003, pag. 96. 
North-South of Europe; for example, the Venetian Republic gathered influences from the most diverse European and extraEuropean cultures.

Folk and court influences interfered with religious ones and resulted in the spectacular evolution of the arts. Hence the cultivation of diversity, the richness of means of expression as well as the meanings and states expressed.

Among the greatness of the Renaissance emerged two emblematic aspects: the Gothic cathedral and the choral art.

We can effectively talk about the "birth" of professional music with a fulminating evolution. The vocal genre reached a moment of artistic peak. During the Renaissance, the composers' preferences were directed mainly towards the vocal music that at that time had the means of expression superior to musical instruments. The situation would gradually change towards the end of the sixteenth century, with the advent of the great Italian luthiers.

The organ was finally accepted in the liturgical service of the Western Church, in the churches become cathedrals. It is easy to imagine that in the beginning the organ did not harmonically accompany the Gregorian monody, but the natural resonance of the sounds emitted by the instrument, in the specific acoustics of the cathedral space, created a great variety of sound vibrations, leading to the gradual rise of musical thinking "on the vertical." "In playing the organ, as would be in the fourteenth century, a text by St. Augustine, updated by Gevaert, reveals that at least two voices were used." 3 The organ keyboard was a Gothic innovation of the $13^{\text {th }}$ century and numerous manuscript illustrations of the epoch indicate the widespread use of organs.

${ }^{3}$ Serge Berstein, Pierre Milza: Istoria Europei, vol. II, De la Imperiul Roman la Europa (sec. V-XIV), Iași, Editura Institutul Europen, 1998, pag. 206 
The greatest music of all time was composed for the church. The choirs were small, counting 20 to 30 people, and the voices were sometimes doubled by instruments. The Roman Church believed that music should be simple and easy to understand, favouring the religious music of Giovanni Pierluigi da Palestrina (1525-1594) with short and intelligible texts, representing the peak of the linear modal polyphony. However, later, Palestrina preferred to write long and rich scores that highlight the choir's qualities. Palestrina's style corrected the excesses in the technique of imitation, which often led to the inability to understand the text. Characterized by stylistic homogeneity, Palestrina synthesized in the predominantly vocal and religious music the whole counterpoint art of the sixteenth century characterized by logic and balance, being a model for contemporaries but also for future generations.

Palestrina's creation was primarily religious: 108 missas, 600 motets, 42 psalms, 200 church and secular madrigals, 9 ricercari for the organ, etc.

Palestrina's style is characterized by a polyphonic, modal religious music, conceived according to very strict melodic and harmonic rules, his language being a synthesis of Renaissance polyphony, especially the Franco-Flemish tradition of the $15^{\text {th }}$ $16^{\text {th }}$ centuries.

The techniques used by Palestrina are as follows:

- maintains the cantus firmus;

- melodic lines consist of sound arches;

- polyphony is modal, imitative;

- the modal system is diatonic;

- Palestrina's use of the counterpoint rejects chromaticism and follows almost all the rules imposed by Zarlino in his theoretical work Le institutioni harmoniche [The Harmonic Institutions], (among them: dissonances must be prepared, brought to unstressed beats and resolved on stressed beats). 
The most prominent followers of Palestrina's art and counterpoint, as well as representatives of the Italian Renaissance making the transition to Baroque music, are Luca Marenzio, Carlo Gesualdo and Claudio Monteverdi.

Luca Marenzio was born in Brescia in 1553 and died in Rome in 1599. Much of his activity took place in Rome, where he held important positions in the service of cardinals. He was extremely admired as an author of madrigals, being referred to as the divine composer.

He traveled through the capitals of Europe with Cardinals Madruzzo and d'Este and settled in Rome in 1593.

In 1595 he left for Poland to the court of Sigismund III Vasa, and afterwards returned to Warsaw.

He was a brilliant exponent of the madrigal technique, illustrating very suggestive ideas or words of the text through specific compositional procedures. He adopted a more chromatic style in his compositions than what was usual at the time, and tended to abandon the modes in favour of minor and major keys. Thus, he opened the way to the new Monteverdi School.

His secular creation is very ample and includes 5 volumes of "Villanelle ed aria alla napolitana" and 24 volumes of madrigals, including Madrigali spirituali, adding over 600 works on 4, 5 and 6 voices, and two books of motets, mostly published in Venice. Besides these, he also composed missas and a series of Sacri concenti.

Starting from Palestrina's tradition, Luca Marenzio cultivates the syllabic declamation, highlighting those passages that recreate the intimate thread of each expressed situation, and regarding the fusion of polyphonic and harmonic thinking, it can be said that he is a composer denoting a full balance of the essential elements of language. At the same time, in his creation, the melody, expressed with much imagination, is well organized rhythmically and metrically, the presence of the diatonic 
chromaticism giving it refinement and elaborate sonority. A convinced polyphonist, he managed to explore the resources offered by chromaticism, and his achievements imposed him as a composer with a strong influence on the English and German madrigals.

Luca Marenzio can be considered as the great classic of the madrigal movement because for him the preoccupation for the content always blended harmoniously with the preoccupation for form. Delightful, tidy and clear, his writing is a testimony to an admirable virtuosity, but is controlled by an expressive sobriety that dominates emotion. Nonetheless, all these features did not prevent him from choosing his texts with a remarkable discernment (Petrarca, Tasso, Guarini) and the descriptive effects of music (the madrigal genre is often referred to as "painting for the ear") ${ }^{4}$, to make the music the echo of the poetic vocabulary of words. Undoubtedly, his refined lyricism is more sensitive to pastoral happiness than to the dramatic traits. Let us add that this master among masters knows how to use the chromatic effect to emphasize emotion and intense feeling, and that to him, the polyphony often opens to the new style of the age, attentive to the suppleness and symmetry of rhythms, to the natural prosody of words and a rather homorhythmic declamation (thus joining the aesthetic program of the Florentine melodramatists).

Gesualdo da Venosa (or Carlo Gesualdo), was born in Naples in 1560 and died in Avellino in 1613. He belonged to a very wealthy noble family in southern Italy. From an early age he showed interest in music and was given a thorough musical education. During his teenage years he composed with great ease and played with virtuosity the lute. After 1590, his biography became controversial.

${ }^{4}$ Max Eisikovits: Polifonia vocală a Renaşterii, Editura Muzicală, București, pag. 121. 
His work is remarkable through an out of the ordinary expressivity and through the bold use of chromatic harmonies, in an unprecedented way at that time.

It consists of 7 volumes of madrigals (the last, published posthumously in 1694) and two books of Sacrae cantiones.

The vision of this great creator goes beyond everything that was written up to that moment. Seeing his talent ever since he was little, his father established a music academy in which the young Carlo was initiated in the art of madrigal construction with the help of Professor Pomponio Nenna. He easily played many instruments (harpsichord, lute), loved literature and poetry - from which he found inspiration when he created his unmistakable dramatic madrigals.

In the first two volumes of madrigals (1578) he used the texts of Torquato Tasso, one of the most famous poets of those times.

The drama of his personal life would reflect in his rich creation fuelled by chromatic resources. All the pages of his manuscripts bear the mark of devastating passions to which he found correspondence in an innovative harmonic language, sometimes tonal, sometimes exceeding its boundaries and in some situations using the total chromaticism.

A composer of great depth, Gesualdo manages to anticipate many elements of construction and compositional technique that prefigure both the Baroque and the other currents that appeared much later. Rising above his era, he anticipates Bach's fugues, Wagner's Romanticism, Schoenberg's chromaticism, or Musorgski, Debussy, Stravinsky, or Bartok in the modal sense.

Gesualdo's favourite genre was the madrigal, to which he devoted six volumes written between 1594 and 1611 on five voices (one on six voices). In his works he uses words with a strong emotional burden (love, death, pain, agony), which pours a sense of constant tension, remorse, and exploration of his inner 
depths, revealing himself in all his grandeur. The melody becomes the determining element of the entire musical discourse. The six volumes of polyphonic choral miniatures are written in a free form, using a diatonic melody, intensely chromatic, in the structure of the Ionian and Aeolian modes.

Gesualdo's art consists not only in the expressive leading of the voices, but in the creation of melodic tensions and harmonic imbalances that find their resolve only in the final cadence, in which the silence of the troubled soul is found.

Labelled as a "unmatched genius," 5 it was due to the fact that he knew how to combine a great wealth of writing regarding the counterpoint with a complex harmonic search, in which chromaticism and suspension (sometimes unresolved) lead to the emergence of long-standing dissonances before his time.

Claudio Zuan Antonio Monteverdi (May 15, 1567, Cremona - November 29, 1643, Venice) is considered the first important figure of modern opera. He reached a degree of unusually high popularity among his contemporaries. His works appear on all major world scenes, his madrigals are long since classical and some sacred pieces are also very well known. He is also known as the father of the opera.

The last great representative of the Renaissance, Claudio Monteverdi, the son of a doctor, was initiated in the mysteries of the polyphony with the help of Marc Antonio Ingegneri, maestro di cappella at the cathedral in the same city and an important polyphonist of the time.

Monteverdi published in 1582 his first collection of motets on three voices, followed by Madrigali spirituali (1583) on four voices and Canzonette d'Amore a tre voci.

5 Larousse- Dicţionar de mari muzicieni, Editura Univers Enciclopedic, București, 2000, pag. 190. 
In 1587 he published the first volumes of secular madrigals on five voices, a volume which is evidenced by the clear detachment of the previous composition, under the influence of maestro Ingegneri. In the following period, he published more volumes of madrigals. Beginning with the third volume of madrigals (1592), Monteverdi intensified his chromatic writing, making it evident that he was detached from the traditional line of the madrigal of Dutch origin, conflicting with the defenders of the old modal way of thinking (Monteverdi's dispute with the Bolognese abbot Artusi, a disciple of Zarlino).

Steady in his belief to intensely express his feelings and experiences, Monteverdi continued his journey of publishing the fourth volume of madrigals, persevering to write in a cappella style but decisively oriented towards the dramatic declamation where the upper voice always supports the melody, and the lower voices appear instrumentally treated.

In 1599 he married the daughter of a musician from the court of the duke of Mantova. He came in contact with several personalities from the world of music, especially with the Florentine Camerata. He published in 1603 Quarto libro de madrigali a cinque voci, and in 1605 Quinto libro de madrigali a cinque voci that achieved the transition from Renaissance style to the Baroque style, representing the central point of controversy with Artusi.

This fifth volume contains works for five voices with the accompaniment of basso continuo, influenced by the Florentine Camerata and the composers who supported it.

In 1607, at the request of Duke Vivenzo, he wrote the lyrical drama Orfeo, the first opera in his creation, which enjoyed a well-deserved success, Monteverdi imposing himself on this occasion as an important musician of the time. After this first genuinely successful drama in musica, his creation acquired new expressive valences derived from the treatment of the voices, 
amplifying the role of the soloist, treating the choir in the same manner of the madrigal spirit.

Through his works, Monteverdi reached a language of his own where fantasy is left to support the artistic truth, managing to express itself in both vocal and instrumental sounds. Gradually, Monteverdi departed with the a cappella imitative style and took the decisive step towards the accompanied melody. A cycle illustrating this manner is the Scherzi musicali a tre voci in which the author fuses between the verve of the French chanson and the cantability of the Italian music.

The genre that represents Monteverdi is the dramatic madrigal emerging from the strong feelings that poetry suggests. The last part of Monteverdi's creation reveals the combination of three manners of creation: the polyphonic, the monodic style and, as a novelty, the recitative linked to the aria. The volume of madrigals that encompasses all of them is called Madrigali guerreri ed amorosi.

Claudio Monteverdi concludes the golden age of the $a$ cappella choral creation, leaving an invaluable heritage in plurivocal and instrumental music.

Returning to the choral creation of the Renaissance, we note the vertiginous evolution of genres and musical forms. All these achievements were possible through the exploitation of vocal resources by the composers of the time.

In the next two volumes of madrigals, the sixth and seventh, from one voice to six voices, the style of the accompanied monody (the solo voice accompanied by basso continuo) marks a decisive change in the manner of composition.

Another moment of reference is the appearance of the eighth volume of Madrigali guerrieri ed amorosi, in which we encounter elements of dramatic cantata - experiments in recitative style. 
The creative power of the great master is noted in the lyrical theatre through works such as the Il ritorno d'Ulisse in patria and L'incoronazione di Poppea.

Monteverdi continues the madrigal tradition with the eight volumes for a cappella choir, but it is also accentuated by madrigals on five voices with basso continuo, harpsichord (cembalo), lute (chitarone), or similar instruments (the fifth volume).

This creative genius is the founder of a new musical style ${ }^{6}$, which is the trigger for a new way, fundamental, in musical thinking. Claudio Monteverdi was educated in the Renaissance culture, from which he adopted its essential elements, being aware that this art can exist both in complex forms and in the simplest sound compositions.

Monteverdi's style is opposite to that of Gesualdo - who made the dramas of his life a splendid motif of inspirational composition. Instead, Monteverdi purified the work of conjunctural experiences - be they of the highest intensity affirming a detached, meditative creative attitude, permanently freed from fashion or from the moment of happening.

The new style proposed by Claudio Monteverdi (the monodic style and the accompanied melody) was born from within himself, from the deep sincerity to the musical truth in whose service he was.

The most known Renaissance musical genres are:

- the motet- religious polyphonic genre, vocal or concerted. It appeared in France in the $13^{\text {th }}$ century, in the Notre Dame School (Ars Antiqua) and has a strophic form. The Renaissance motet changed significantly from the medieval motet. Compared to the isorhythmic writing of the first stage (in which the voices

6 Mario Carrozzo- Cristina Cimagalli: Storia della musica occidentale, Armando Editore, Roma, 2003, vol. I, pag. 186. 
evolved at the same time, based on the same rhythmic formulas), the Renaissance motet was built on polyphonic imitation, vocal, with religious text (not necessarily liturgical). The number of voices varies from 2 to 16, but most often 4 or 5 voices are preferred. Essentially, the Renaissance motet has many similarities to the madrigal; therefore it can be considered a madrigal with religious text and character. The Renaissance motet has an episodic format in the movement of the phrases with different text sections and musical content. In the $16^{\text {th }}-17^{\text {th }}$ centuries, the motet often becomes a concerted genre. It also generated the emergence of new musical genres such as the ricercar, oratorio etc. Other stages in the evolution of the genre of motet were the Baroque motet (the great motet), the classic motet and the neoclassical motet;

- the madrigal- polyphonic genre, vocal a cappella, with secular text and character. The term derives from the genre cantus materialis - in the musical practice of the fourteenth century (Ars Nova or Early Renaissance) gradually became matrialis, matriale, madriale, madrigal. The term 'madrigal' apparently comes from the French rondel and the Italian frotolla. In the first stage of existence, the genre was interpreted by voices and instruments, the latter doubling the vocal parts. Influences from religious and folk music are intertwined in the madrigal. The form is strophic or with episodic phrases. Throughout the Renaissance, the genre evolves into more and more complex types, culminating in the dramatic madrigal - considered one of the sources of the opera genre.

Through the secular character, detached from the rigours imposed by the religious cult, the content and form, the text and the music of the madrigal gained great malleability. The madrigal sets alongside not only the religious with the secular, but also folk music with the cultivated (elaborated), as well as the main cultural areas of the time (from the fifteenth-sixteenth centuries) - 
Italian, French, Flemish, German, English. There are also two interpretative directions: virtuosity, as well as expressiveness. Originally polyphonic, resembling the motet, the genre of the madrigal evolves throughout the sixteenth century to the accompanied monody - from the prima pratica, to the seconda pratica. During the late Renaissance, which coincided with the beginnings of the Baroque, the Madrigal gained broader dimensions, bringing together in its musical discourse diverse structures, from recitative to monody, duo, trio, chorus, as well as elements of the concert style.

Masters of the Renaissance madrigal genre were Luzzasco Luzzaschi 1540-1607, Luca Marenzio 1533-1599, Carlo Gesualdo, Principe di Venosa 1560-1614, Claudio Monteverdi 1567-1643.

The Renaissance brings a completely new way of thinking, a vision directed at the human universe, to man's rights to earthly happiness. Secular influences pervade also the religious music. The Gregorian chant was conceived for a vast acoustic space.

Antiphonal singing was not a Renaissance invention. The technique of a dialogue between two groups of singers, spatially located, is mentioned in the ancient Greek writings. The $16^{\text {th }}$ century Venetian School cultivated predominantly the antiphonal writing, up to compositional refinements, which brought to light the unique acoustic space offered by the two organs of the San Marco Cathedral: dynamic contrasts and echo effects, rhythmic, melodic and of timbre. All these formed the beginning of the conscious concern of the composers to include the acoustic space among the elements of musical language. Thus were born the first stereophonic forms of music, called by the Venetians of the sixteenth century cori spezzati. In the same manner appeared the combinations of voices and instruments; finally, the purely instrumental genres were included in the musical manifestations hosted by the Cathedral of San Marco. 
The Venetian school was active for at least a century, starting with the arrival of the Flemish Adrien Wilaert in 1527, until the middle of the following century, when Claudio Monteverdi was working as chapel master at San Marco.

The representatives of the Renaissance Venetian School develop the idea of pluralizing voices in writing for double choirs, spatialised in various galleries. The sound effect of the double-spatialized chorus stereophony, through alternations and responses, was first obtained by Adrien Wilaert and his disciple Andrea Gabrieli. Andrea's nephew, Giovanni Gabrieli, created similar sound effects in instrumental music, sonata pian ed forte and canzoni, interpreted by small groups of string and wind instruments.

The Greek-cross layout with a dome of the San Marco Basilica, with the choir balconies in the transept's arms, seems to have suggested to the composers some unusual acoustic possibilities. These spezzati choirs - split choirs instil Venetian music with an element of spatial contrast, also creating new colour effects. Among these effects, we find the echo, so important in the entire Baroque tradition.

The musical discourse often shows the alternation of two contrasting sound elements:

- alternating choirs (antiphonal style);

- separate voice lines against the entire choir;

- instruments opposed to voices;

- contrasts between instruments;

- alternation between high and low voices;

- alternations of weak and strong dynamic levels (echo effect);

- alternations of continuous and fragmentary elements;

- compact chords on the one hand, with the contrapuntal interplay of the many melodic lines on the other;

- abrupt chords, in contrast to contrapuntal fluency. 
This principle of duality also had other long-lasting results: the concert style and the imitative counterpoint. The latter would dominate the polyphonic musical language of the first half of the $18^{\text {th }}$ century, fitting perfectly in the tonal organization system. The term appears in the title of works published by Giovanni Gabrieli, together with his uncle Andrea, in 1587.

During the Renaissance, the foundations of the suite and the instrumental sonata are laid out. The Late Renaissance marks the emergence of the innovative genre of the opera, and in the field of choral music appear the cantata and the oratorio, genres of ample proportions. All these denote that the Renaissance period was a milestone in the subsequent evolution of world music.

\section{References}

1. Dicţionar de Termeni Muzicali, Editura Enciclopedică, Bucureşti 2008.

2. Eugenio Garin, L'Umanesimo Italiano. Filosofia e Vita Civile nel Rinascimento, Bari, 1954.

3. Frédéric Lemerle, Yves Pauwels, L'architecture à la Renaissance, Flammarion, Paris, 2003.

4. Georges Duby, Arta și societatea. $\quad 980-1420$, vol. I, II, București, Editura Meridiane, 1987.

5. Jean Delumeau, La civilisation de la Renaissance, Flammarion, Paris, 1984.

6. Jeffery C. Smith, The Northern Renaissance, Phaidon, Londra, 2006.

7. Larousse - Dicţionar de mari muzicieni, Editura Univers Enciclopedic, Bucureşti, 2000.

8. Marco Della Sciucca, Giovanni Pierluigi da Palestrina, L'Epos Società Editrice, Palermo 2009.

9. Mario Carrozzo - Cristina Cimagalli, Storia della musica occidentale, Armando Editore, Roma 2003, voll. I-II.

10. Max Eisikovits: Polifonia vocală a Renașterii. Stilul palestrinian, Editura Muzicală, București, 1966 
11. Ovidiu Drâmba, Istoria culturii și civilizației, vol. 3, București, Editura Științifică, 1990.

12. Philippe Morel, L'art de la Renaissance entre science et magie, Rennes, 2005.

13. Riccardo Allorto, Nuova storia della musica, Ricordi, Roma 1992.

14. Serge Berstein, Pierre Milza, Istoria Europei, vol II, De la Imperiul Roman la Europa (secoleleV - XIV), Iași, Editura Institutul European, 1998.

15. Volker Reinhardt, Die Renaissance in Italien. Geschichte und Kultur, Beck, München, 2002 